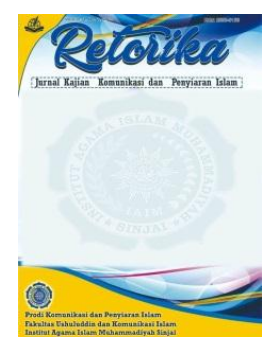

RETORIKA

Jurnal Kajian Komunikasi dan Penyiaran Islam

Volume 3, No. 12021

P-ISSN: 2655-5166

E-ISSN: $2715-2103$

Homepage : http://journal.iaimsinjai.ac.id/indeks.php/retorika

\title{
Analisis Perkembangan Islam Di Perancis
}

\author{
Faridah $^{1}$, Herawati Syamsul ${ }^{2}$, Asriadi $^{3}$ \\ ${ }^{I}$ Institut Agama Islam Muhammadiyah Sinjai, Sinjai \\ Email; andifaridah81@gmail.com Telepon +6285242364718 \\ ${ }^{2}$ Universitas Indonesia Timur, Makassar \\ Email: heraandipatta@gmail.com Telepon + 6282191755077 \\ ${ }_{3}^{3}$ Institut Agama Islam Muhammadiyah Sinjai, Sinjai \\ Email: asriadiaccy92@gmail.com Telepon +6285343688717
}

\begin{abstract}
Abstrak:
Tulisan ini membahas tentang analisis Perkembangan Islam Di Perancis yang diuraikan dari beberapa aspek yakni Proses Islamisasi, Perkembangan dan Problematika serta Eksistensi Umat Islam di Perancis Dewasa ini. Hasil penelusuruan dari berbagai kajian ilmiah mengungkapkan bahwa Proses Islamisasi di Prancis terjadi melalui jalur peperangan yakni pada masa perang salib kemudian melalui jalur perdagangan. Dan di masa perkembangannya proses Islamisasi di Prancis terjadi melalui jalur dakwah dan perkawinan. Adapun perkembangan Islam di Prancis terus berialan dinamis dari tahun ke tahun dan dewasa ini terdapat 25 persen warga Prancis telah memeluk Islam, meskipun berkembang dinamis namun kehidupan umat Islam di Prancis diwarnai oleh beragam problematika yang cukup pelik seperti pelarangan penggunaan jilbab bagi kaum Muslimah. Namun eksistensi umat Islam di Prancis dewasa ini dapat dilihat dari kemampuan mereka bertahan hidup melawan situasi dan kondisi yang mengitarinya. Mereka tetap antusias dalam menjalankan ajaran agamanya seperti pelaksanaan ibadah-ibadah secara rutin semisal shalat,puasa dan zakat, dan lain sebagainya.
\end{abstract}

Kata Kunci: Analisis, Perkembangan Islam. 
Volume 3, No. 12021

P-ISSN: 2655-5166

E-ISSN: $2715-2103$

Homepage : http://journal.iaimsinjai.ac.id/indeks.php/retorika

\section{PENDAHULUAN}

Negara Prancis merupakan negara tertua ke tiga di dunia setelah Ethiopia dan San Marino. Di bidang ekonomi, Negara ini memiliki tingkat kestabilan ekonomi ke 4 dan memiliki kekuatan militer pada urutan nomor 6 di dunia. Prancis dapat dikatakan sebagai negeri dengan panorama, budaya, dan tempat wisata eksotis di dunia. ${ }^{1}$

Berdasarkan letak geografisnya, Negara Prancis merupakan salah satu negara di benua Eropa yang berbatasan dengan beberapa negara Eropa lainnya yakni dari Utara berbatasan dengan Serat Inggris, dari Timur berbatasan dengan Swiss dan Italia, dari Selatan berbatasan dengan Laut Tengah dan Spanyol dan dari Barat berbatasan dengan Teluk Biscay. ${ }^{2}$

Ibukota dari Negara Prancis adalah Paris yang dijuluki kota cahaya, Negara perancis juga dikenal dengan sebutan negeri Mode di Dunia. Di Negara ini terdapat satu keajaiban dunia yaitu Menara Eifel yang terletak di Kota Paris. Di samping itu, Negara perancis juga terkenal di bidang kuliner, anggur, music, seni, kereta api supercepat TGV, resor-resor sky di Pegunungan Alpen dan pusat pusat wisata lainnya. Sektor pariwisata menyumbangkan devisa yang sangat besar bagi Negara ini. ${ }^{3}$

Terdapat beberapa agama yang dianut oleh masyarakat Prancis dan agama yang medominasi adalah agama Katolik, agama lain yang dianut adalah Islam, Yahudi dan Budha. Berdasarkan hasil survei juga diketahui bahwa terdapat 23\% penduduk tidak menganut agama apapun (ateis). ${ }^{4}$

Negara Prancis merupakan negara yang menjunjung sekularisme. laicite atau sekularisme negara dalam identitas nasional Perancis menduduki posisi sentral dan menjadi bagian yang tidak terpisahkan dari moto pasca revolusi, yaitu "liberty, equality, fraternity". 5 Di samping sekulerisme, Prancis juga menganut paham liberal. Sekulerisme adalah paham yang menganggap bahwa

\footnotetext{
${ }^{1}$ https://www.geografi.org/2017/11/negara-perancis.html, diakses Senin 12 April 2021

2 https://virtueducation.org/letak-astronomis-perancis, diakses Senin 12 April 2021

3 https://www.geografi.org/2017/11/negara-perancis.html, diakses Senin, 12 April 2021

4 https://virtueducation.org/letak-astronomis-perancis, diakses Senin, 12 April 2021

5 https://www.bbc.com/indonesia/dunia-54630462, di akses senin 12 April 2021.
} 
Volume 3, No. 12021

P-ISSN: 2655-5166

E-ISSN: 2715-2103

Homepage : http://journal.iaimsinjai.ac.id/indeks.php/retorika

agama itu tidak ada urusan dengan dunia, negara dan sebagainya. Sekularisme menginginkan agama dipisahkan dari kehidupan sosial. Agama hanyalah dianggap sebagai urusan individu dengan Tuhan. ${ }^{6}$

Namun, pada perkembangannya, sistem sekularisme yang awalnya ditujukan untuk menjamin kebebasan beragama, dalam beberapa tahun terakhir justru dijadikan tameng untuk membatasi bahkan mengubah nilai-nilai keagamaan. Rencana separatisme Macron sendiri, mencakup perombakan sebagian dari cara Islam diatur di Prancis, dari pelatihan para imam hingga manajemen asosiasi Muslim. $^{7}$

Proyek anti-separatisme tersebut juga memusatkan perhatian terhadap nilai yang dijunjung dari sekularisme 'laicite' dalam bahasa Prancis yang diabadikan dalam Konstitusi negara itu. Menurut Tareq Oubrou seorang imam terkemuka di Bordeaux, kehadiran Islam bukanlah sesuatu yang diramalkan oleh masyarakat Prancis. "Muslim telah direduksi dari agamanya sendiri," ujar Oubrou. Meningkatnya ketegangan pernah terjadi sebelumnya ketika ada perubahan pada UU sekularisme dengan aturan pelarangan hijab di ruang kelas pada tahun 2004 dan larangan memakai penutup wajah (niqab) pada tahun $2010 .^{8}$

Berdasarkan informasi beberapa media, Muslim di Prancis merupakan populasi Muslim terbesar di Eropa Barat. Namun, pemeluknya sampai saat ini masih terbayang-bayangi oleh diskriminasi, diperkirakan 5 juta Muslim di negara itu masih harus berjuang keras untuk mendapatkan pengakuan dan penerimaan penuh dari lingkungannya. Sorotan kecurigaan yang diarahkan pada mereka semakin terasa setelah serangan yang menewaskan Samuel Paty, disusul pernyataan Presiden Emmanuel_Macron yang berupaya 'membersihkan' Islam di

${ }^{6}$ https://pmb.lipi.go.id/meneropong-konflik-agama-islam-di-perancis-sebuah-eksklusisosial-terhadap-islam (12 November 2020), diakses Minggu 18 April 2021.

${ }^{7}$ https://republika.co.id/berita/qj6fli320/umat-islam-di-prancis-korban-stigmaisasi-dansekularisme, diakses Senin, 12 April 2021

${ }^{8}$ https://www.kompas.com/global/read/2020/11/02/072346570/dapat-stigma-akibat-terordi-perancis-umat-islam-merasa-tertekan?page=all (Kompas.com - 02/11/2020, 07:23 WIB), diakses

Senin, 12

April

2021 
Volume 3, No. 12021

P-ISSN: 2655-5166

E-ISSN: $2715-2103$

Homepage : http://journal.iaimsinjai.ac.id/indeks.php/retorika

Prancis dari para ekstremis dan istilah yang dipergunakan adalah separatisme Islam. $^{9}$

Menurut Macron seperti dikutip di media, "Islam mengalami krisis di banyak negara, tidak cuma di Prancis". Adapun Langkah yang disiapkan pemerintah Perancis dan dimasukkan ke parlemen pada akhir tahun mencakup beberapa hal yang meliputi:

1. Pengawasan yang lebih ketat terhadap organisasi olahraga dan perkumpulan

lain sehingga tak menjadi medium pengajaran Islam,

2. Imam tak boleh didatangkan dari luar Perancis,

3. Peningkatan pengawasan pendanaan masjid,

4. Pembatasan home-schooling. ${ }^{10}$

Kebijakan Presiden Macron merupakan suatu langkah yang dianggap untuk mengantisipasi pergolakan dan kekacauan di negaranya, kekacauan tersebut sesungguhnya berawal dari bulan Januari tahun 2015 ketika Charlie Hebdo, sebuah majalah Prancis memasang karikatur yang melecehkan Nabi Muhammad di sampul majalahnya. Akibatnya, 12 orang pekerja terbunuh. Serangan selanjutnya terjadi 25 September lalu, seorang pengungsi asal Pakistan di laporkan melukai dua orang di lokasi bekas kantor Charlie Hebdo. ${ }^{11}$

Beberapa rangkaian peristiwa berdarah yang mewarnai pergolakan di Prancis seperti dikutip dalam media dapat dilihat sebagai berikut:

1. Dua pria militan Islam memaksa masuk ke kantor Charlie Hebdo dan menembak mati 12 orang pada Januari 2015.

2. Pria bersenjata dan pelaku bom bunuh diri melancarkan berbagai serangan terkoordinasi di gedung konser Bataclan, stadion utama, restoran, dan bar di Paris, menyebabkan 130 orang tewas dan ratusan lainnya luka-luka, peristiwa ini terjadi pada November 2015.

\footnotetext{
${ }^{9}$ https://republika.co.id/berita/qj6fli320/umat-islam-di-prancis-korban-stigmaisasi-dansekularisme, diakses Senin, 12 April 2021

${ }^{10}$ Sekularisme Prancis: Karikatur Nabi Muhammad, 'separatisme Islam', sikap Presiden Macron dan tiga serangan teror dalam sebulan, https://www.bbc.com/indonesia/dunia-54630462 (31 Oktober 2020)

${ }^{11}$ https://republika.co.id/berita/qj6fli320/umat-islam-di-prancis-korban-stigmaisasi-dansekularisme, diakses Senin, 12 April 2021.
} 
Volume 3, No. 12021

P-ISSN: 2655-5166

E-ISSN: $2715-2103$

Homepage : http://journal.iaimsinjai.ac.id/indeks.php/retorika

3. Seorang pria bersenjata mengendarai truk besar ke kerumunan yang merayakan Hari Bastille di Nice, menewaskan 86 orang dalam serangan yang diklaim oleh kelompok Negara Islam (IS), terjadi Juli 2016.

4. Dua penyerang membunuh seorang pendeta, Jacques Hamel, dan secara serius melukai sandera lainnya setelah menyerbu sebuah gereja di pinggiran Rouen di Prancis utara, terjadi Juli 2016.

5. Operator komputer polisi, Mickaël Harpon, ditembak mati setelah menikam hingga tewas tiga petugas dan seorang pekerja sipil di markas polisi Paris, hal ini terjadi pada Oktober 2019.

6. Dua orang ditikam dan terluka parah di Paris dekat bekas kantor tabloid Charlie Hebdo, tempat militan melakukan serangan mematikan pada tahun 2015, peristiwa ini terjadi September 2020.

7. Guru bahasa Prancis Samuel Paty dipenggal kepalanya di luar sekolah di pinggiran kota Paris, terjadi Oktober 2020. ${ }^{12}$

Setelah peristiwa Samuel Paty, kejadian ini disusul serangan yang menewaskan tiga orang di sebuah gereja di kota selatan Nice, yang diduga dilakukan oleh seorang pemuda Tunisia. Adapun insiden Samuel Paty yang terjadi pada tanggal 16 Oktober 2021 oleh seorang pengungsi remaja asal Chechnya disinyalir akibat tindakan Samuel Paty yang menunjukkan karikatur Nabi Muhammad di kelasnya. $^{13}$

Peristiwa ini seolah semakin mengukuhkan upaya Presiden Macron sehingga mengumumkan langkah baru mengatasi hal yang disebutnya "separatisme Islam" di Prancis, Langkah ini meliputi pembuatan rancangan undang-undang luas untuk mencegah radikalisasi yang di antaranya mencakup:

1. Pembatasan sekolah rumah dan pemberian hukuman lebih berat kepada mereka yang mengintimidasi pejabat publik dengan menggunakan dalih agama

\footnotetext{
${ }^{12}$ Prancis dalam kondisi syok' setelah serangan bertubi-tubi, Presiden Macron klarifikasi pernyataan tentang kartun kontroversial, https://www.bbc.com/indonesia/dunia-54766954 (1 November 2020) diakses Senin, 12 April 2021

${ }^{13}$ https://republika.co.id/berita/qj6fli320/umat-islam-di-prancis-korban-stigmaisasi-dansekularisme, (2 Nov 2020 ) diakses Senin, 12 April 2021.
} 
Volume 3, No. 12021

P-ISSN: 2655-5166

E-ISSN: 2715-2103

Homepage : http://journal.iaimsinjai.ac.id/indeks.php/retorika

2. Memberikan nomer indentifikasi kepada anak-anak untuk memastikan mereka bersekolah

3. Orang tua yang melanggar peraturan dapat diancam dengan hukuman penjara maksimal enam bulan dan juga denda besar

4. Larangan memberikan informasi pribadi yang memungkinkan keberadaan orang tersebut dapat dilacak oleh mereka yang ingin mengancam keselamatannya. $^{14}$

Berbagai kebijakan dari persiden Immanuel Macron tersebut telah menuai aksi keras internasional, Namun Macron mengatakan dan meyakini bahwa reaksi keras dari negara-negara Muslim karena orang-orang telah salah memahami bahwa dia mendukung kartun itu, atau bahwa kartun itu dibuat oleh pemerintah Perancis. ${ }^{15}$

Berdasarkan pemaparan tersebut dapat diketahui dan dipahami tentang eksistensi Islam dan kehidupan pemeluknya di Negara Prancis. Namun lebih jauh kita terinspirasi untuk lehih mengetahui dan mendalami tentang proses Islamisasi di Negara Prancis, Problematikan muslim Prancis serta perkembangan Agama Islam di sana.

\section{METODE}

Penelitian ini merupakan kajian pustaka dengan jenis penelitian kualitatif, pendekatan penelitian yang peneliti gunakan adalah pendekatan komunikasi dan dakwah. Peneliti dalam penelitian ini berusaha mengumpulkan data dengan cara mengkaji literatur-literatur yang terkait dengan tema penelitian yakni perkembangan Islam di Negara Prancis, jadi Teknik pengumpulan data yang peneliti gunakan adalah Teknik dokumentasi.

${ }^{14}$ Para pemuka Muslim Prancis diberi ultimatum dua minggu untuk menerima piagam 'nilai-nilai republik' (20 November 2020) Lihat Juga Serangan di Prancis: Macron menyerukan reformasi kebijakan perbatasan Uni Eropa

https://www.bbc.com/indonesia/dunia-55017602 (07 November 2020)

${ }^{15}$ Lihat Juga Prancis dalam kondisi syok' setelah serangan bertubi-tubi, Presiden Macron klarifikasi pernyataan tentang kartun kontroversial, https://www.bbc.com/indonesia/dunia$\underline{54766954}$ (1 November 2020)) 
Volume 3, No. 12021

P-ISSN: 2655-5166

E-ISSN: $2715-2103$

Homepage : http://journal.iaimsinjai.ac.id/indeks.php/retorika

Data yang peneliti kumpulkan harus peneliti analisis dengan menggunakan reduksi data, kemudian melakukan display daya dan terakhir melakukan ferivikasi data atau melakukan penyimpulan data.

\section{PEMBAHASAN}

\section{Proses Islamisasi di Prancis}

Proses penyebaran dan penerimaan Islam di suatu daerah terjadi melalui beberapa upaya, hal ini lazim disebut dengan istilah Islamisasi. Menurut. Ahmad Sewang dalam Suparto Iribaram, Islamisasi adalah suatu proses yang tidak pernah berhenti sejak pertama kali datangnya Islam yakni adanya penerimaan dan penyebaran lebih lanjut tentang Islam hingga saat sekarang. ${ }^{16}$ Islamisasi ini terjadi di setiap negara-negara di dunia termasuk Negara Prancis, yakni salah satu negara yang berada di benua Eropa.

Negara Prancis yang beribukotakan Paris merupakan Negara Republik dengan sistem pemerintahan parlementer konstitusional. Negara ini memiliki luas wilayah 47.030 KM, bahasa nasionalnya adalah bahasa Prancis, dan kurs mata uangnya adalah Franc. Prancis merupakan wilayah terbesar di Eropa Barat, yang luasnya hampir seperlima luas seluruh wilayah Eropa. ${ }^{17}$ Penduduknya berjumlah 59. 551.227 jiwa yang terdiri dari berbagai etnik diantaranya Celtik dan Latin. ${ }^{18}$

Masuknya Islam di Prancis diperkirakan terjadi sejak abad ke 8 M. Islam masuk ke kota-kota selatan Prancis melalui Spanyol ke Toulouse, Narbonne dan sekitarnya hingga Bourgogne yang berada di tengah-tengah Prancis. Namun baru pada abad 12 hingga abad 15 orang-orang Islam mulai menempati kota-kota selatan Perancis yang terdapat di provinsi Roussillon, Languedoc, Provence, Pay Basque Perancis termasuk Bearn. Hal ini berlangsung secara bertahap dan puncaknya adalah ketika terjadi pengusiran besar-besaran terhadap muslim Spanyol pada peristiwa Reconquista di bawah Raja Ferdinand II dan istrinya ratu Isabel pada tahun $1492 \mathrm{M}$.

\footnotetext{
${ }^{16}$ Suparto Iribaram, Proses Islamisasi, perkembangan, dan eksistensi Islam di Perancis, Tasamuh Jurnal Studi Islam (September 2018).

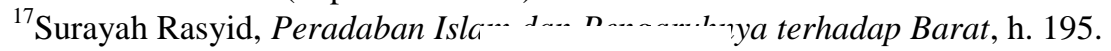

${ }^{18}$ https://id.wikipedia.org/wiki/Islam_di_P 9
} 
Volume 3, No. 12021

P-ISSN: 2655-5166

E-ISSN: $2715-2103$

Homepage : http://journal.iaimsinjai.ac.id/indeks.php/retorika

Dari sumber lain dinyatakan bahwa Proses Islamisasi di Prancis diperkirakan bermula sejak terjadinya perang salib, yakni sekitar abad ke 11 sampai ke 13 M, kemudian proses Islamisasi tersebut terjadi pada tahun 1830, yakni ketika imigran muslim berdatangan membawa barang dagangan mereka ke Prancis. Pertama, disebut proses Islamisasi melalui jalur peperangan dan yang kedua di sebut Islamisasi melalui jalur perdagangan. Pada masa-masa berikutnya proses Islamisasi di Prancis melalui jalur dakwah dan perkawinan ${ }^{19}$

Tahap Islamisasi berikutnya terjadi setelah Perang Dunia I dan II. Pada saat ini, sebagian muslim yang masuk ke Prancis adalah para korban perang dari Palestina, Turki, Tunisia dan lain-lain. Sementara sebagian besar lagi datang dari AL-Jazair sekitar tahun 1960-an karena Prancis membutuhkan sejumlah besar tenaga dalam rangka membangun negaranya yang hancur karena perang.

Kehadiran warga muslim di Prancis tidak lepas dari sejarah kolonial di negeri itu. Di Afrika Utara, antara lain Tunisia dan Maroko, dan juga adanya hubungan khusus antara Prancis dan Al-Jazair (Al-Jazair sampai tahun 1962 tidak dianggap sebagai negara koloni tetapi sebagai bagian dari Prancis). Pada periode tersebut Prancis merekrut warga AL-Jazair untuk menjadi tentara diangkatan persenjataannya maupun di kalangan buruh. ${ }^{20}$

Masyarakat Prancis, sudah lama mengalami kontak dengan Islam. Tepatnya sejak Islam masuk pada abad 8 di bagian Selatan Prancis, yakni di saat transisi kekuasaan dari Dinasti Bani Ummayyah ke Dinasti bani Abbasiyah. ${ }^{21}$ Islam berkuasa selama kurang lebih 40 tahun. Demikian pula pada abad ke sepuluh Islam mencoba memperluas kekuasaan daerah kekuasaannya, tetapi gagal sebab di abad pertengahan ini, Islam menghadapi perang salib dan akhirnya mereka meninggalkan Prancis. ${ }^{22}$ Selanjutnya, bangsa Prancis pernah menginjakan

19 Kebangkitan Islam di Prancis, Populasi Muslim Terbesar Eropa, republika.co.id (Jumat 10 Jul 2020 04:58 WIB) diakses, lihat juga https://id.wikipedia.org/wiki/Islam_di_Prancis

${ }^{20}$ Surayah Rasyid, Peradaban Islam dan Pengaruhnya terhadap Barat, h. 201.

${ }^{21}$ Ira M. Lapidus, A. History Of Islamic Societies diterjemahkan oleh Ghufran A Mas'adi dengan judul, Sejarah sosial umat Islam Bagian Kesatu dan Kedua (Cet. I; Jakarta PT. RajaGrafindo Persada.1999), h. 102.

${ }^{22}$ John L. Esposito, The oxford encyclopedia of the modern Islam World, Vol.2 (New York: Oxfoed University Press, 1995), h. 28. 
Volume 3, No. 12021

P-ISSN: 2655-5166

E-ISSN: $2715-2103$

Homepage : http://journal.iaimsinjai.ac.id/indeks.php/retorika

kakinya di Mesir di saat Napoleon menaklukkan Mesir pada tahun $1878 .^{23}$

Penaklukan ini, sebenarnya sudah lama diinginkan oleh Raja Louis XIV untuk memudahkan jalur perdagangan melalui laut merah dan laut tengah menuju ke timur dan ke India. $^{24}$ Prancis telah mengenal dunia Islam sejalan dengan penjajahan yang dilakukannya terhadap wilayah-wilayah yang berpenduduk mayoritas Muslim di Al-Jazair, Maroko, Tunisia, Senegal, Mali, Libanon, Mesir dan selainnya. Seperti Negara Industri lainnya, Perancis juga membuka kesempatan kepada just arbeiders yaitu buruh tamu dari Tunisia, Maroko, AlJazair, Turki, dan sebagainya untuk bermukim di Perancis.

Kehadiran Islam di Prancis bersamaan dengan colonialisasi Afrika utara yang dimulai pada tahun $1830 \mathrm{M}$. Pada pedagang yang dikenal dengan istilah Turcos datang dari Al-Jazair setelah tahun $1850 \mathrm{M}$, menyusul kemudian imigran Maroko yang bekerja di dermaga Marseiiles, di kotruksi bagian selatan selama perang dunia I, para migran yang berjumlah lebih dari 132.000 orang Afrika Utara, berdomisili di Prancis sebagai pekerja sawah dan buruh di pabrik senjata, serta lebih dari 1500 orang diminta untuk terlibat dalam peperangan

Seiring dengan perkembangan waktu, jumlah orang Islam di Prancis bertambah dan semakin plural. Hal ini ditandai dengan hadirnya pedagang Turki, Afrika (Senegal, Mali, Mauritania), Timur Tengah (Iran, Afganistan, Pakistan).

Berdasar pada keterangan-keterangan di atas, maka dapat dipahami bahwa proses Islamisasi di Prancis, telah dimulai sejak terjadinya perang salib dan secara eksplisit proses islamisasi di Prancis dimulai pada tahun 1830, yakni ketika imigran muslim berdatangan membawa barang dagangan mereka ke Prancis. Dengan demikian, dapat dikatakan bahwa prosess islamisasi di Prancis pada awalnya melalui jalur peperangan dan proses selanjutnya adalah jalur perdagangan. Dalam masa-masa perkembangannya, proses Islamisasi di Prancis tetap berjalan, namun yang terakhir ini proses proses Islamisasi melalui jalur dakwah dan perkawinan, karena di sana sudah banyak ummat Islam menetap.

\footnotetext{
${ }^{23}$ Sayyed Hosen Nasr, A. Young Moslem's Guide to Modern World. Di terjemahkan oleh Hasti Tariakat dengan judul Menjelajah Dunia Moden (Bandung: Mizan, 1994), h. 126.

${ }^{24}$ Hasan Ibrahim hasan, Islamic History and Culture, diterjemahkan oleh Djahdan Human dengan judul Sejarah dan Kebudayaan Islam (Cet. I;Yokyakarta: kota kembang, 1989), h. 351.
} 
Volume 3, No. 12021

P-ISSN: 2655-5166

E-ISSN: 2715-2103

Homepage : http://journal.iaimsinjai.ac.id/indeks.php/retorika

\section{Perkembangan Islam di Prancis}

Masyarakat muslim Eropa tersebar di tiga negara, termasuk di antaranya di negara Prancis. Umat Islam yang tinggal di negara Prancis jumlahnya terbesar dibandingkan dengan yang ada di negara Eropa lainnya, seperti Jerman dan Inggris. Jumlah angka muslim mencapai angka lima juta jiwa. ${ }^{25}$

Saat ini Agama Islam menduduki posisi ke-tiga agama yang dianut oleh masyarakat Prancis menyusul Yahudi di urutan ke-dua dan Katolik di urutan ketiga, bahkan diprediksi Agama Islam di Prancis akan menempati urutan ke-dua setelah Katolik di tahun $2040 .^{26}$

Populasi muslim di Prancis agak sulit untuk ditentukan jumlahnya secara pasti namun hal itu bisa dilakukan dengan mempekirakannya berdasarkan rujukan dari berbagai sumber. Tindakan ini dapat membantu dalam memprediksi secara akurat populasi muslim Negara Prancis. Berkaitan dengan ini, maka penulis akan mengungkapkan beberapa data yang diberikan oleh Jhon L. Esposito yang menyatakan bahwa:

1. Terdapat Imigrasi muslim yang telah menetap lama di Prancis berjumlah 1.593.907 jiwa yang terdiri dari Al-Jazair 614.707 jiwa, Tunisia 206.336 jiwa.dan sebanyak 197.712 dari Turki. ${ }^{27}$

2. Penduduk hasil Imigrasi yakni orang Al-Jazair yang berkebangsaan Prancis, mereka memperoleh kemerdekaanya dari Prancis, mereka berjumlah sekitar 500.00 jiwa. Pada tahun 1920 Al-Jazair dan Maroko bermigrasi ke Perancis karena pada saat itu Prancis membutuhkan tenaga buruh untuk rekonstruksi pasca perang dunia I sekitar 140.000 jiwa.

3. Penduduk yang berjuluk Prancis Baru yakni muslim yang mendapatkan kewarganegaran akibat kelahiran atau melalui naturalisasi.

4. Komunitas Prancis yang memeluk Islam. Komunitas ini memiliki peran penting dalam memberikan mediasi antara masyarakat muslim dengan masyarakat Prancis pada umumnya. ${ }^{28}$

\footnotetext{
${ }^{25}$ Surayah Rasyid, Peradaban Islam dan Pengaruhnya terhadap Barat, h.200.

${ }^{26}$ Syamsudduha Saleh, Sejarah Peradaban Islam, Forum Ilmiah, Minggu, 25 April 2021.

${ }^{27}$ John L. Esposito, The oxford encyclopedia of the modern Islam World, Vol. 2, h. 28-29.

${ }^{28}$ Surayah Rasyid, Peradaban Islam dan Pengaruhnya terhadap Barat, h.200.
} 
Volume 3, No. 12021

P-ISSN: 2655-5166

E-ISSN: $2715-2103$

Homepage : http://journal.iaimsinjai.ac.id/indeks.php/retorika

Secara nasional dan natural, penduduk yang diuraikan dalam kategori tersebut di atas dianggap sebagai penduduk asli Prancis, merekalah yang dianggap mengetahui seluk budaya dan pradaban masyarakat Prancis.

Mengingat bahwa umat Islam terus mengalami perkembangan dari tahun ke tahun, terutama melalui jalur dakwah dan pernikahan, maka diperkirakan bahwa untuk tahun-tahun berikutnya, populasi umat Islam di Prancis memiliki pertambahan yang signifikan.

Hanya saja, menurut Jhon L. Esposito bahwa irama dan ritme kehidupan sehari-hari masyarakat Prancis tampak semakin kompetitif dan terkadang diisi dengan konflik di masyarakat yang tidak begitu ramah menyambut keberadaan umat Islam. Disamping itu norma dan nilai kehidupan di Prancis begitu sulit dimengerti dalam populasi yang begitu plural semacam ini. Identitas muslim sebagai sebuah sarana budaya merupakan salah satu diantara tumbuhnya sentimen tersebut. Walaupun demikian kelihatan bahwa perkembangan Islam secara kuantitas di Perancis akan terus meningkat, mengingat Islam akan terus dianut oleh mereka yang terlahir dari keturunan muslim yang secara konsisten memegang teguh ajaran agamanya.

\section{Problematika dan Eksistensi Umat Islam di Prancis Dewasa Ini}

Umat Islam di Prancis terus mengalami perkembangan dari tahun ke tahun, hal ini terutama melalui jalur dakwah dan pernikahan. Sehingga dapat diperkirakan bahwa populasi umat Islam di Prancis mengalami perkembangan yang signifikan secara kuantitatif. Namun seiring perkembangannya, ternyata umat Islam di Prancis menghadapi problematika yang cukup pelik hal ini terutama disebabkan oleh pelarangan menggunakan jilbab bagi kaum muslimah. Walaupun demikian, kelihatannya umat Islam di Perancis dewasa tetap eksis dan mampu bertahan hidup melawan situasi yang mengitarinya. ${ }^{29}$

Berdasarkan data statistik dari Agence Pour le Développement des Relations Interculturelles (ADRI) jumlah penduduk Muslim di Perancis terus meningkat, pada tahun 2000 terdapat 150 ribu Muslim dari sekitar 1,8 juta

\footnotetext{
${ }^{29}$ Salmah Intan, Islam di Perancis (Islamisasi, Perkembangan, dan Eksitensi), http://journal.uin-alauddin.ac.id/index.php/al_hikmah/article/view/9765 (2019)
} 
Volume 3, No. 12021

P-ISSN: 2655-5166

E-ISSN: 2715-2103

Homepage : http://journal.iaimsinjai.ac.id/indeks.php/retorika

penduduk di kota Lyon. Sementara di Paris, jumlah Muslim mencapai 1,7 juta dari sekitar 12 juta warganya. Kota pelabuhan Marseille dan Lille juga memiliki jumlah Muslim sama banyak, yaitu 200 ribu orang. Dengan total penduduk Marseille yang 800 ribu orang, artinya 25 persen warganya memeluk Islam. Islam adalah agama yang berkembang paling cepat di Perancis. Dengan jumlah Muslim lima juta orang pada tahun 2017, dan 7 juta jiwa pada tahun 2020. Perancis menjadi negara yang memiliki warga Muslim terbanyak di Eropa, disusul Jerman sekitar empat juta jiwa dan Inggris sekitar tiga juta jiwa. ${ }^{30}$

Adapun corak dan paham keagamaan yang dianut oleh masyarakat muslim Prancis adalah berpaham Sunni, namun terdapat wilayah muslim tertentu di Prancis yang secara kuat berciri campuran. ${ }^{31}$ Berdasarkan pemaparan tersebut, diketahui dan dapat dianalisis bahwa perkembangan Islam di Negara Prancis cukup pesat dan kehidupan umat Islam cukup damai dalam lingkup intern umat Islam. Namun, pluralisme masyarakat terutama dari eksternal (non-muslim) menjadi salah satu faktor pemicu terjadinya konflik di tengah-tengah masyarakat dan problematika yang dihadapi oleh umat Islam Perancis dewasa ini.

Tragedi terdahsyat dunia di awal abad ke 21 yang terjadi pada tanggal 11 September 2001 di Amerika merupakan awal diskriminasi terhadap umat Islam, peristiwa tersebut dijadikan sebagai dalih untuk menekan umat Islam di Eropa baik melalui agen polisi, perekonomian, politik maupun propoganda. ${ }^{32}$ Menganalisis problematika kehidupan muslim di Prancis dapat ditarik kesimpulan bahwa tekanan yang dialami oleh muslim Prancis bersumber dari dua arah yaitu pemerintah dan media massa.

Tekanan demi tekanan yang dialami oleh muslim Prancis tidak membuat mereka surut dan menyerah, mereka tetap eksis bahkan mampu bertahan hidup walaupun mereka harus berlawanan dengan masyarakat non-muslim pluralis dan sekuler. Adapun perkembangan Islam di Negara Prancis terus terjadi salah

30 https://pmb.lipi.go.id/meneropong-konflik-agama-islam-di-perancis-sebuah-eksklusisosial-terhadap-islam (12 November 2020), diakses Minggu 18 April 2021.

${ }^{31}$ Wahyu Ilaihi dan Harjani Hefni, Pengantar Sejarah Dakwah, Jakarta: Kencana, 2012, h.216.

${ }^{32}$ H.A.R Gibb, Islam dalam Lintasan Sejarah (Cet. IV; Jakarta: Bhratara Karya Aksara, 1983), h. 57. 
Volume 3, No. 12021

P-ISSN: 2655-5166

E-ISSN: 2715-2103

Homepage : http://journal.iaimsinjai.ac.id/indeks.php/retorika

satunya melalui para imigran dari Afrika, seperti Aljazair, Libya, Maroko, Mauritania, dan lainnya. Sekitar 1960-an, ribuan buruh Arab berimigrasi (hijrah) secara besar-besaran ke daratan Eropa, terutama di Prancis. Hal ini berdampak pada melonjaknya jumlah penganut agama Islam di Prancis. Peran buruh migran asal Afrika dan sebagian Asia membuat agama Islam berkembang dengan pesat. Mereka mendirikan komunitas atau organisasi untuk mengembangkan Islam. Secara perlahan- lahan, penduduk Prancis pun makin banyak yang memeluk Islam. Karena pengaruhnya yang demikian pesat itu, Pemerintah Prancis sempat melarang buruh migran melakukan penyebaran agama, khususnya Islam. ${ }^{33}$

Pada tahun 1970-an, imigran Muslim kembali mendatangi negara pencetus trias politica itu. Kali ini, para pelajar Muslim yang datang ke Prancis untuk menuntut ilmu. Kedatangan para pelajar ini menjadi faktor penting yang mengambil peran besar dalam mendorong penyebaran Islam di jantung negeri Napoleon Bonaparte ini. Secara perlahan, para imigran muslim tersebut mulai menunjukkan jati diri, dan identitas keislaman mereka. Ini diwujudkan melalui pembangunan masjid dan pusat-pusat keIslaman, mendirikan organisasi Islam Prancis, serta secara aktif dalam menyampaikan ajaran Islam kepada orang lain. ${ }^{34}$

Pada 1985, diselenggarakan konferensi besar Islam yang dibiayai Rabithah Alam Islami (Organisasi Islam Dunia). Turut serta dalam konferensi itu 141 negara Islam dengan keputusan mendirikan Federasi Muslim Prancis. Hasil konferensi dan terbentuknya federasi Muslim itu berhasil mempersatukan sebanyak 540 buah organisasi Islam di seluruh Perancis dan melindungi 1.600 buah masjid, lembaga-lembaga pendidikan Islam, dan gedung-gedung milik umat Islam. Dengan kondisi ini, barisan umat Islam pun semakin kokoh. Yang lebih menggembirakan lagi, kebanyakan anggota federasi yang menjalankan roda orga

\footnotetext{
${ }^{33}$ Kebangkitan Islam di Prancis, Populasi Muslim Terbesar Eropa, republika.co.id (Jumat 10 Jul 2020 04:58 WIB) diakses Minggu 18 April 2021

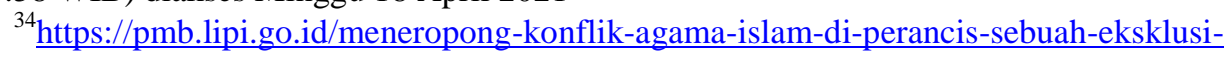
sosial-terhadap-islam (12 November 2020), diakses Minggu 18 April 2021.
} 
Volume 3, No. 12021

P-ISSN: 2655-5166

E-ISSN: $2715-2103$

Homepage : http://journal.iaimsinjai.ac.id/indeks.php/retorika

nisasi justru berasal dari kaum muda-mudi Muslim berkebangsaan Prancis sendiri. $^{35}$

Pada tahun 1981, pemerintah Prancis menerapkan kembali ketentuan undang-undang yang memberikan hak kepada orang asing untuk berserikat, momen ini menumbuhkan spirit kemunculan organisasi-organisasi Islam di seluruh Prancis yang menjadi bagian dari dinamika Gerakan dakwah di negara Prancis. Berdasarkan kajian dan Gerakan dakwahnya, organisasi dakwah di Prancis terbagi atas dua bagian yaitu:

1. Organisasi Islam yang memiliki kegiatan bersifat dakwah dan berbagai layanan keagamaan bagi anggotanya, memiliki beragam orientasi seperti Foi et Pratique (imam dan praktik) merupakan cabang dari Gerakan dakwah jamaah tabligh.

2. Organisasi yang berciri kurang Islam dibanding organisasi dalam poin satu. Kebanyakan berusia muda dan cenderung mengaitkan diri dengan kebudayaan negeri asal-usul mereka, seperti Generation Egalite (generasi kesamaan) dan Generation Beur (Generasi Imigram Afrika Utara). ${ }^{36}$

Banyaknya organisasi Islam di Prancis yang di antaranya berperan untuk pelaksanaan dakwah menjadikan Islam di Prancis semakin berkembang, di samping itu banyaknya ditemukan masjid menjadi indikasi bahwa kaum muslim Prancis dewasa ini senantiasa antusias dalam menjalankan ibadah-ibadah secara rutin, terutama shalat berjamaah. Praktis bahwa ajaran Islam yang lain, semisal puasa dan zakat juga terlaksana dengan baik.

Berbagai fenomena yang digambarkan tersebut merupakan indikator bahwa meskipun mendapatkan beragam tantangan seperti dinyatakan oleh Malik Idris dalam Faridah tentang ragam tantangan dakwah yang terdiri atas tantangan dakwah persepektif perilaku, perpektif transmisi, persepektif interaksi dan

${ }^{35}$ Kebangkitan Islam di Prancis, Populasi Muslim Terbesar Eropa, republika.co.id (Jumat 10 Jul 2020 04:58 WIB) diakses, lihat juga https://id.wikipedia.org/wiki/Islam_di_Prancis

217.

\footnotetext{
${ }^{36}$ Wahyu Ilaihi dan Harjani Hefni, Pengantar Sejarah Dakwah, Jakarta: Kencana, H.216-
} 
Volume 3, No. 12021

P-ISSN: 2655-5166

E-ISSN: 2715-2103

Homepage : http://journal.iaimsinjai.ac.id/indeks.php/retorika

persepektif transaksional, ${ }^{37}$ perkembangan Islam di negara Prancis tetap dinamis dan mengalami peningkatan dari segi kuantitas, tentunya hal ini diharapkan berbarengan dengan peningkatan dari segi kualitas juga ke depannya.

\section{KESIMPULAN}

Proses Islamisasi di Prancis terjadi sejak perang salib dan juga di katakan dimulai pada tahun 1830, yakni ketika imigran muslim berdatangan membawa barang dagangan mereka ke Prancis. Adapun metode islamisasi di Prancis pada awalnya melalui jalur peperangan kemudian melalui jalur perdagangan. Dan di masa perkembangannya proses Islamisasi di Prancis terjadi melalui jalur dakwah dan perkawinan.

Perkembangan Islam di Prancis terus berjalan dinamis dari tahun ke tahun. pada tahun 2000 terdapat 150 ribu Muslim dari sekitar 1,8 juta penduduk di kota Lyon. Sementara di Paris, jumlah Muslim mencapai 1,7 juta dari sekitar 12 juta warganya. Kota pelabuhan Marseille dan Lille juga memiliki jumlah Muslim sama banyak, yaitu 200 ribu orang. Dengan total penduduk Marseille yang 800 ribu orang, artinya 25 persen warga Prancis telah memeluk Islam dan diperkirakan tahun 2040 Agama Islam di Prancis mencapai urutan ke-dua setelah Katolik.

Umat Islam di Prancis hidup dalam beragam tantangan, beragam problematika yang cukup pelik harus mereka hadapi seperti pelarangan penggunaan jilbab bagi kaum Muslimah dan ragam aturan lainnya yang mengekang ekspresi beragama bagi muslim Prancis. Namun umat Islam di Prancis dewasa ini tetap eksis, dan mereka mampu bertahan hidup melawan situasi dan kondisi yang mengitarinya. Mereka tetap antusias dalam menjalankan ajaran agamanya seperti pelaksanaan ibadah-ibadah secara rutin semisal shalat,puasa dan zakat, dan lain sebagainya.

\footnotetext{
${ }^{37}$ Faridah, Urgensi Implementasi Strategi Dakwah Di Era Kontemporer, https://doi.org/10.47435/mimbar.v2i1.273, h. 51.
} 


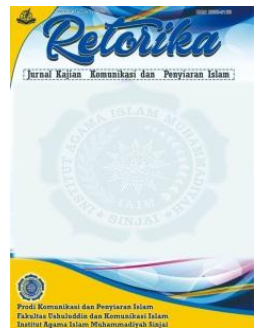

RETORIKA

Jurnal Kajian Komunikasi dan Penyiaran Islam

Volume 3, No. 12021

P-ISSN: 2655-5166

E-ISSN: $2715-2103$

Homepage : http://journal.iaimsinjai.ac.id/indeks.php/retorika

\section{DAFTAR PUSTAKA}

Azra, Azyumardi. Pergolatan Politik Islam: Dari Fundamentalisme,Modernisme hingga Post-Modernisme. Cet. I; Jakarta: Paramadina, 1996.

Esposito, Jhon L. The oxford Encyclopedia of the Modern Islam World, Vol. 2. New York: oxford university Press, 1995.

Faridah, Urgensi Implementasi Strategi Dakwah Di Era Kontemporer, https://doi.org/10.47435/mimbar.v2i1.273.

Gayo, Iwan. Buku pintar seri senior, plus 20 Negara Baru.Jakarta: Upaya Warga Negara, 2000.

Hasan, Ibrahim Hasan. Islamic History and Culture, diterjemahkan oleh Djahdan Human dengan judul Sejarah dan Kebudayaan Islam. Yogyakarta: Kota Kembang, 1989.

Wahyu Ilaihi dan Harjani Hefni, Pengantar Sejarah Dakwah, Jakarta: Kencana, 2012.

https://pmb.lipi.go.id/meneropong-konflik-agama-islam-di-perancis-sebuaheksklusi-sosial-terhadap-islam (12 November 2020), diakses Minggu 18 April 2021.

https://republika.co.id/berita/qj6fli320/umat-islam-di-prancis-korban-stigmaisasidan-sekularisme, diakses Senin, 12 April 2021

https://www.bbc.com/indonesia/dunia-54630462, Sekularisme Prancis: Karikatur Nabi Muhammad, 'separatisme Islam', sikap Presiden Macron dan tiga serangan teror dalam sebulan, (31 Oktober 2020).

https://www.bbc.com/indonesia/dunia-54630462, di akses senin 12 April 2021.

https://www.kompas.com/global/read/2020/11/02/072346570/dapat-stigma-

akibat-teror-di-perancis-umat-islam-merasa-tertekan?page $=$ all

(Kompas.com - 02/11/2020, 07:23 WIB), diakses Senin, 12 April 2021

https://id.wikipedia.org/wiki/Islam_di_Prancis lihat juga Kebangkitan Islam di Prancis, Populasi Muslim Terbesar Eropa, republika.co.id (Jumat 10 Jul 2020 04:58 WIB) diakses ,

Lapidus, Ira M. A History of Islamic societies diterjemahkan oleh Ghufran

A. Mas'adi dengan judul, Sejarah sosial umat Islam bagian kesatu dan kedua.

Cet. I; Jakarta: Pt.Rajagrafindo Persada, 1999.

Nasr, Sayyed Husen. A. young Moslem's Guide to Modern World,

diterjemahkan oleh Hasti Tarikat dengan judul menjelajah Dunia Modern.

Bandung; Mizan, 1994.

Rasyid, Surayah. Peradaban Islam dan Pengaruhnya terhadap Barat. Alauddin University Press: Makassar, 2014.

Sewang, Ahmad M. Islamisasi Kerajaan Gowa: Abad XVI sampai Abad XVII. Yayasan Obor Indonesia: Jakarta, 2005.

Eksitensi),

Salmah Intan, Islam di Perancis (Islamisasi, Perkembangan, dan alauddin.ac.id/index.php/al_hikmah/article/view/9765 (2019) http://journal.uin-

Yatim, Badri. Sejarah Peradaban Islam. Cet. II; Jakarta: PT. RajaGrafindo Persada, 1994. 